\title{
Traditional Shalish system for rural dispute resolution in Bangladesh: An analytical study of its structure and operational mechanism
}

\author{
Muhammad Rafiqul Hoque \\ PhD Candidate, Universiti Sains Islam Malyasia (USIM) \\ International Islamic University Chittagong (IIUC), Bangladesh \\ Muhammad Mustaqim Mohd Zarif \\ Faculty of Qur'anic and Sunnah Studies \\ Universiti Sains Islam Malaysia (USIM), Malaysia
}

\begin{abstract}
This study aims at exploring the structure and operational mechanism of Shalish-a traditional rural dispute resolution system in Bangladesh. It seems that this dispute resolution system, being very informal and flexible in nature, has no organized structure and operational mechanism. However, this paper aims to critically investigate the situation. Based on observation of a number of Shalish events in a rural area of the country and extensive discussion with some Shalishkars and disputants, this qualitative study finds that the system is well structured and its operational mechanism is quite effective, albeit with some limitations. It is recommended that a local Alim (Islamic Scholar) should be included in all Shalish to ensure shari'ab related issues like some family and inheritance related disputes. Shalishkears need to be trained and upgraded in their experiences and qualities through workshops, seminars in respect of legal, moral and shari'a issues.
\end{abstract}

Keywords Shalish, Dispute Resolution, Traditional Shalish

Paper type Research paper

\section{Introduction}

The traditional Shalish system is the most commonly used method of dealing with both civil and criminal disputes resolution in Bangladesh. About 60-70\% of rural disputes are resolved through this system (Islam, 2009: 101). An informal dispute resolution committee of different types exists almost everywhere in Bangladesh especially in rural areas from time immemorial. Shalish system in Bangladesh is based on custom and tradition of the society. Thus, it is a customary and traditional Shalish. It helps restore community harmony formally and informally. For being not guided by any

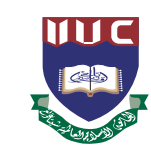

IIUC Studies Vol. 16, Dec. 2019 pp. $35-56$ (C) IIUC

ISSN 1813-7733 
regulation, it is often viewed that it has no structure and organized operational mechanism. Thus, literatures hardly talk about the structure and operational techniques of Shalish. This study is an attempt to meet this gap and examine the structure and operational mechanism of traditional Shalish for dispute resolution in rural Bangladesh.

\section{Methodology}

This study followed a qualitative method of research to explore the applied structure and operational mechanism of traditional Shalish system for dispute resolution in rural Bangladesh. It is based on both primary and secondary data. Secondary data were collected through a review of relevant published and unpublished documents \& reports, books, journals and periodicals. Primary data were collected through careful observations of 11 Shalish meetings and interview of a large number of Shalishkars of various categories, disputants, UP members and chairmen, a family court judge, and legal personnel totaling 46 interviewees in some villages of Sylhet, Sunamgonj and Chattogram districts of Bangladesh. Observation of the real Shalish events took place since the beginning of 2017 to the mid of 2019. As an observer, the researcher did not take any part to influence the procedure of the events but kept the observation and recorded the whole process in a recorder, which has been transcribed into written text and then translated into English. All interviewees gave their consent prior to the interviews and were spontaneous in their responses to the questions. At the time of the observation, the questions that arose in the mind of the researcher got clarified taking interviews from various categories of Shalishkars, disputants or other stakeholders of Shalish.

\section{Definition of the term "Shalish"}

Shalish in Arabic is thalith(ن) meaning third (Muhammad, 2000). It is derived from Arabic word Thalatha (salasa) meaning three. In relation to mediation it, therefore, means intervention of a third party for amicable settlement of a dispute between two conflicting parties (Islam, 2000: 1). The word is similar to the Arabic word Salis that means third, used in the sense of middle man (Hoque, 2018). Some of the scholars opine that Shalish is a Persian word meaning mediation (Alim \& Rafi, 2003). In fact, the word Shalishkear is Persian not the word Shalish. As the word is not Bengali, people are accustomed to use the word according to their understanding. The word is pronounced as salis, Shalish or sallish in different areas of the country (Shahidullah, 2009). In this study, it is used to mean mediation, conciliation, arbitration or any other intervention of a neutral third party to settle any dispute amicably. It is a body (committee) of selected local notable members 
called Shalishkars. The 'Banglapedia' defines Shalish as a social system for informal adjudication of petty disputes both civil and criminal, by local notables, such as matbars (leaders) or Shalishkears (adjudicators) (Islam, 2003). A notable person doing a Shalish is a Shalishkar. He is also named differently like matbor, dana, dewani, darbari etc. in different places of the country. The Shalish hearing is a public event and participatory in nature. Any person who has been wronged can call for a public hearing. Occasionally the elders themselves may call a Shalish if they feel that community codes of conduct are in jeopardy (Siddiki, 2003). It therefore provides a traditional alternative to dispute resolution in a community (Munni, 1996). Shalish is an indigenous, a traditional dispute resolution system which is usually used in Bangladesh. It refers to a community-based, largely informal process through which small panels of influential local figures help resolve community members' disputes. By doing so they help the disputants come to a compromise and settle their dispute peacefully. Sometimes they impose their decision on them (Golub, 2003: 2-3). This conventional system of mediation is deeply rooted in the history, culture and humanities of Bangladesh.

\section{Importance of Shalish}

Bangladesh is a densely populated country and most of its population live in rural area. According to Population \& Housing Census 2011, 76.70\% populations reside in rural area (Census, 2011). Dispute is a common phenomenon of every human society, but the formal courts of the country are located in the district headquarters away from rural people. Moreover, formal courts are overburdened with huge pending litigations, which was according to a government report in the year 2008, 1,826,682 case (Barkat, Paddar, Khan, \& Ullah, 2012). More than 35.82 lacs cases are pending with the higher and lower courts as stated by Law minister in the parliament on June 17, 2019. In order to dispose the loads of cases Shalish can play an important role also. It is quite impossible to provide judicial services for the entire rural population by formal courts. A Shalish has opportunity more than the court to offer a suitable resolution. For a court has no chance to see the cause of dispute exactly. The Shalishkars know people personally. Moreover, when the disputant invites them for a Shalish, the disputing parties describe the problem to them from their own. That is why they can settle the dispute peacefully. If any party fails to comply with a peaceful settlement proposed by the Shalishkars, the Shalishkars go to adjudicate maintaining justice properly. Regarding this reality an Advocate honestly remarks that-

"A Shalish has more opportunity to offer a suitable resolution than the court. For a court has no chance to see the cause of dispute exactly" (Interview34_16032019). 
The importance of Shalish as a dispute resolution process lies in the fact that two-thirds of rural disputes do not enter the formal court process. In other words, this huge number of rural dispute is resolved by traditional Shalish and nowadays also by NGO-led Shalish, village courts, and arbitration councils (Islam, 2015). However, most of these are being done by traditional Shalish. Access to the Shalish does not require a high degree of literacy. The formal justice system in Bangladesh is under tremendous pressure with much workload and an inadequate number of officials and staff to dispose the cases. Considering the huge backlogs, excessive delays, outrageous expenses and uncertain outcomes of the formal legal system, Shalish is hugely important for resolving disputes in rural communities. Again, as there is no formal administrative unit at the village level, this Shalish system provides social administration to the villagers (Barman, 1988). It plays a role like a formal guardian for the villagers (Md. Abdul Alim, 2004: 4). Shalish being community based rural institutions closest to the people, is in the best position to understand community problems and peoples' need for quick, acceptable and affordable justice delivery (Delwar, 2005: 26).

\section{Historical background}

Historically Panchayat was rural administrative unit with judicial responsibility in the Indian subcontinent (n.a, n.d). Panchayat means a body of five wise persons. The term "panchayat" implies an assembly of five or more persons (Sarker, 2013). It still exists all over Bangladesh in the form of panchayat or samaj. Panchayat or samaj is nowadays the rural community consisting of heads of the families residing in an area sharing a common interest. The samaj is a traditional association of people having jurisdiction over a certain area within a village community. It is used with panchayat interchangeably. During the ancient period, usually the king nominated or the people of respective villages elected panchayat. The esteemed members of the Village Panchayat were responsible for the distribution of land among the villagers and for tax collection. The panchayat in ancient Northern India and elsewhere in the subcontinent, including Bengal, was the lowest tier of local government, which also functioned as a court having jurisdiction over members of different castes and occupations belonging to the same village (Islam, 2003). The initial development of the panchayat was a spontaneous phenomenon to meet the social needs, and they were quite independent in their working. The panchayat had jurisdiction over almost every type of dispute arising in the village community. They used to decide both civil and criminal cases.

The Muslim rulers later constituted their own system of judicature, which was at variance with the traditional system, but they virtually did not 
touch the existing village panchayat. However, the jurisdiction and authority of panchayat was declined with the establishment of formal courts for adjudicating civil and criminal cases during the British rule in India. The new land system introduced by the British also adversely affected the panchayat justice system. Yet, the British rule recognized the panchayat justice arrangement unofficially. Some historians believed that the village panchayat was either non-existent or very weak in the region where Bangladesh is now located. Hence, a highly organized Shalish system was unlikely to have operated here at any period (Islam, 2003). It is found through this study also that Shalish is known all over the country but people use somaj (community) instead panchayat in some areas (interview 14_11022019). The local mediation during the early British period in this part of the subcontinent seems to have comprised adjudication of petty disputes relating to social matters mostly through neighborhood Shalish; and land related, inter-neighborhood or inter-village disputes through the zamindar or his agents. Later, when population increased and neighborhoods expanded, there were both neighborhood and village-based adjudications. With the strength of the zamindari system eroding over time and the growth of the formal courts, adjudication by zamindars or their officials in the rural areas gradually became defunct. In other words, Shalish in Bengal villages seems unlikely to have been associated with a well-developed rural local government system. Whatever existed here was highly informal in nature and was dictated by the practical situation prevailing at the grassroots level.

The incidence of localized disputes and altercations continued to increase as the number of people and communities within the village structure continued to increase to share the limited community resources. Consequently, the village identity took a firmer shape on one hand, and the number of neighborhoods increased on the other. The village-based Shalish also emerged either as an addition to or as a replacement of the neighborhood Shalish. In this phase, inter-village Shalish also came into being. Shalish is meant to be a medium for out-of-court settlement of petty quarrels or disputes in the rural society.

Shalish thus emerged as a need-based rural dispute system. It has been practiced over the years for community level dispute resolution. When a dispute arises between two individuals or groups, and either of the parties report it to some elderly people having social status, then they sit together with the parties and other concerned to resolve it. It is generally a public event and in most cases, disputes are settled amicably through compromise or arbitrarily if it needs so (Islam, 2012). The Shalish remains the dominant means of adjudication for small-scale civil and criminal disputes. It refers to 
a small-scale local council which is convened for conflict resolution, an institution which dates back to pre-British times (Lewis, 2005).

\section{Case study to analyze structure and operational mechanism}

To understand the nature, feature, structure and operations of the village Shalish some of the Shalish cases at a village were observed by the researcher practically during February 2017 to March 2019. The purpose of these observations was to evaluate the system and to suggest the necessary improvement. The cases have been used to analyze the structure and operational mechanism of the system under the table below:

\section{An analysis of the cases in terms of structure and operational mechanism of Shalish}

Table 1: Cases stating the nature and kinds of disputes and their resolutions

\begin{tabular}{|c|c|c|c|}
\hline S.L & Statement of the disputes & $\begin{array}{c}\text { Nature of } \\
\text { the disputes }\end{array}$ & $\begin{array}{r}\text { Resolution } \\
\text { through "Shalish" }\end{array}$ \\
\hline $\begin{array}{l}\text { Case } \\
01\end{array}$ & $\begin{array}{l}\text { Quarrel between two children resulting a } \\
\text { bigger fight between two hamlets }\end{array}$ & $\begin{array}{l}\text { Behavioral, Social, } \\
\text { criminal }\end{array}$ & $\overline{\text { resolved }}$ \\
\hline $\begin{array}{l}\text { Case } \\
02\end{array}$ & $\begin{array}{l}\text { Land property transfer delaying officially } \\
\text { though the possession established by the } \\
\text { purchaser for } 25 \text { years }\end{array}$ & Moral, social, civil & Not resolved \\
\hline $\begin{array}{l}\text { Case } \\
03\end{array}$ & $\begin{array}{l}\text { Illegal occupation of land property at the } \\
\text { absence of the main owner }\end{array}$ & Moral, social, civil & $\begin{array}{r}\text { Resolved finally by } \\
\text { the disputants } \\
\text { themselves taking } \\
\text { help of their relatives }\end{array}$ \\
\hline $\begin{array}{l}\text { Case } \\
04\end{array}$ & $\begin{array}{l}\text { Selling a piece of land interchanged } \\
\text { without written document } 35 \text { years back }\end{array}$ & $\begin{array}{l}\text { Moral, social, Civil \& } \\
\text { criminal }\end{array}$ & resolved \\
\hline $\begin{array}{l}\text { Case } \\
05\end{array}$ & Violence against a woman & $\begin{array}{l}\text { Moral, social, } \\
\text { criminal }\end{array}$ & resolved \\
\hline $\begin{array}{l}\text { Case } \\
06\end{array}$ & $\begin{array}{l}\text { matrimonial dispute based on wife's } \\
\text { physical dissatisfaction }\end{array}$ & Family, civil & resolved \\
\hline $\begin{array}{l}\text { Case } \\
07\end{array}$ & $\begin{array}{l}\text { Intra-village inter hamlets dispute based } \\
\text { on common interest }\end{array}$ & Social, civil & $\begin{array}{l}\text { Resolved through } \\
\text { greater shalish }\end{array}$ \\
\hline $\begin{array}{l}\text { Case } \\
08\end{array}$ & $\begin{array}{l}\text { inter family dispute base on behavioral } \\
\text { inconsistency }\end{array}$ & $\begin{array}{l}\text { Social, Behavioral, } \\
\text { criminal }\end{array}$ & $\begin{array}{r}\text { Resolved through } \\
\text { clan shalish }\end{array}$ \\
\hline $\begin{array}{l}\text { Case } \\
09\end{array}$ & $\begin{array}{l}\text { inter village dispute based on common } \\
\text { interest }\end{array}$ & Social, civil & Not resolved \\
\hline $\begin{array}{l}\text { Case } \\
10\end{array}$ & $\begin{array}{l}\text { family dispute based on husband's ill } \\
\text { motive to marry again }\end{array}$ & Family, civil & $\begin{array}{r}\text { Resolved based on } \\
\text { fatwa }\end{array}$ \\
\hline $\begin{array}{l}\text { Case } \\
11\end{array}$ & $\begin{array}{l}\text { Intra-village intergroup fighting based } \\
\text { on illegal power exercising }\end{array}$ & Social, criminal & $\begin{array}{r}\text { Resolved through } \\
\text { greater shalish }\end{array}$ \\
\hline
\end{tabular}

The table: 01 shows that two cases $(06 \& 10)$ are related with family and the rest are related with social issues. So based on domain, the dispute may belong to a family dispute or a social one. Family issues could be related with 
matrimonial issue where husband and wife are two parties. On the other hand, in social issue two groups consisting of two families or two hamlets or even two villages are the parties. Social disputes could be caused by behavioral transgression, or transgression on other's rights. A family dispute brings consequence to a family level. On the other hand, a social dispute creates a disorder in a society. Both the family and social disputes are divided into cases of civil or criminal in nature. To resolve a dispute its relationship with the parties and the nature of the issue must be considered. For example, a family dispute based on matrimonial relationship necessarily brings some related issues to be solved by the Shalishkears, namely issue of dower, maintenance, custody of children and so on. Social issues are also to be resolved with all its related issues. It has been found that the Shalishkars used to divide the cases into two general categories, civil and criminal.

\section{Summary of the cases studied}

Generally, all these Shalish events give us a structure and a procedure. An applicant or a complainant, an accused or defendant, Shalishkears, issue of a dispute and an outcome are the main elements of a Shalish structure and all Shalish meetings. Again, to reach a decision the Shalishkars have to follow a procedure. Procedures may vary from Shalish to Shalish but the main elements of the Shalish remain same.

The first case of Shalish was about a case of making mountain out of a mole. It starts from disagreement between two boys that turned into a big fight. The Shalishkars followed a very simple procedure to settle it. An interim third party arranged the Shalish for the disputing parties on condition that the fighting is stopped. The Shalish heard the statements and simple arguments from both parties and some arguments and comments from the audience. Influential and sincere advice from the Shalishkars acted upon the disputants positively and opened the space for settlement easily.

The second case of Shalish was about a land dispute. It was the second meeting in this regard. Another Shalish meeting was held before. For some technical fault from the claimant's part, the defendant took an aggressive stand. Shalishkars tried to convince him (the defendant) and let the case be settled by the men of their own hamlet. They did not follow up the case later. This may be seen as a weakness of traditional Shalish system.

The third case of Shalish was about an illegal occupying of a piece of land. Both disputing parties were shareholders in the same area through inheritance. The complainant had a piece of land changed from another shareholder 35 years back without any written document. Therefore, the 
piece remained under the previous record owner. In this gap, the defendant purchased that piece of land from the previous right owner officially after 35 years. The defendant occupied the land claiming that he has purchased it and accordingly he built a hut on it. On request of complainants who were in abroad, a Shalish was formed consisting Shalishkars from nearby villages. It took several sessions and in every session, an oral report has been made briefly from the body of main Shalishkars about previous sessions. It may be considered as the efficiency of the Shalish and competency of the Shalishkars that they maintain a system recorded in their memory. The Shalishkars tried to settle the matter through either compromise or adjudication or blended of two, but they failed to declare any decision for uncompromising mentality of defendant party. The defending party in this case was in a mood not to comply the decision of the Shalish. After the fifth session, it was stopped for about one year without any sitting. Finally, one of the main applicants of the Shalish came home from abroad in February 2019 and it started again to move. The neutral neighbors of the same hamlet along with the disputants took initiative again and resolved the issue amicably. It ended on March 2019 starting from February 2017. The important feature of this Shalish meeting was that the Shalishkars followed a systematic procedure, which could impress anyone interested to know about traditional Shalish. Based on necessity, Shalishkars invited some external expert from outside and took their help.

The fourth case of Shalish was about a piece of land exchanged without any written document. Though a written deed and its registration under proper registry office was deemed necessary for this kind of interchange, it was left undone. The interchanged pieces of land remained officially under its previous record of rights owners. In this gap, one of the parties immorally claimed to have their interchanged land back after around 35 years just to create a problem. It became target of some troublemakers to inspire this party to do a treachery. Main Shalishkars identified this party as wrongdoers and suggested to let the pieces of lands be registered by each for other. However, the cheating complainant party does not like to settle the dispute through the Shalish fairly.

The fifth case of Shalish represents violence against a woman in the same hamlet. The people of same hamlet formed a Shalish but the injured woman was not satisfied for undue dominance of the offender party. Another greater Shalish consisting of Shalishkars from nearby villages settled the dispute after the aggrieved party filed a case to the nearby police station. It has been observed that a woman keeping connection with an NGO was 
related to the case in favor of the victim woman. Whatever be there, violence against women is seen a very hateful criminal offence in the eyes of state law and Islamic laws.

This sixth case of Shalish was about a family dispute. It started with the problem from the first night. The bride was very young and immature to manage a situation gently. Finally, the gap between them began wider and wider until the divorce happen within five months after the marriage was held. A family Shalish consisting of guardians from both families along with some neutral persons resolve the dispute amicably. Sexual dissatisfaction is a major fact for dispute in conjugal life.

The seventh case of Shalish was about a community property dispute. Community property receives no proper attention in rural area. People fail to own it and availing this opportunity some people try to grasp the public property wrongly. This case was a result of such an internal competition to grasp a community property. Finally, for collective resistance people saved their property.

The eighth case of Shalish was about an inter-family disputes based on behavioral inconsistency. Two young boys being influenced by their mother attacked on their nearest relative neighbor. The boys transgressed the limit and breached social and Islamic norms through violating the blood tie. A Shalish was formed consisting of people of same hamlet. The Shalishkars resolve the dispute making the offenders apologies to the aggrieved party. It imposed a fine of tk 5000.00 to recover some damage made by the offenders. Proper family education is highly needed to avoid this kind of offence.

The ninth case of Shalish was about community interest. Two villages took an initiative to dig some big ponds for their community development purpose. It needed shifting few meters of a local road and they did it accordingly. People from another village protested it after the road had been shifted. Only ego of the opposite party was the main reason of the dispute. A neutral third party tries to resolve the matter but for the egoistic refusal, the opposite party failed to comply it. It increased nothing but trouble for opposite party. From the last report, the opposite party is not using this road for it leads them to go across their counterpart area.

The tenth case of Shalish was about a matrimonial dispute. A one-sided three pronouncements of divorce from the husband through a legal notice in written text was the issue of the dispute. He stated that he did it intentionally with his full conscience. Ulama opined that it would come to effect as three talaq and final separation were there. There was no ambiguity 
in his utterance. However, based on the state law, the Muslim Family Law Ordinance 1961, it was supposed to be accepted as one talaq revocable only. The husband tried to get his wife back. But based on Ulamas' opinion wife's family did not agree with it. They said that it is a matter of halal and haram and they should rely on fatwa rather than statutory law. It may be noted here that triple talaq in a session is considered only one talaq according to the law. Based on a fatwa of Imam ibn Taymiyah almost all Muslim countries codified it to their statutory Muslim family laws. It needs a separate examination.

The eleventh case of Shalish was about dominance of a clan over all other clans of a village. Most of the villagers were against the dominant clan. A big fight took place between two clans at around mid night. Some Shalishkars arrived the spot and took initiative to stop fighting. Next day these Shalishkars met the parties again and made them agree to come to settle their disputes through a Shalish. Some people from both parties were hospitalized. Therefore, Shalishkars had to wait to arrange the Shalish until the injured people come back home. The result of the incident remained unknown. However, this event shows how Shalish interfere all types of cases in rural areas regardless of its gravity. As Shalishkars play an important role to stop fighting instantly. They must have to see the matter also. That is why we see where village court has to settle the case within its jurisdiction, Shalish has unlimited jurisdiction allowed by the social norms. Scholars may criticize Shalish for its interfering to all the cases from legal viewpoint. However, this Shalish is the first tool to stop fighting quickly. Of course, they need to know the legal boundary and take their steps within its obligation. This study found that the Shalishkears are sincere about it also. They deal with a case of severe injury or a murder case tactfully without violating the state law.

\subsection{Structure of Shalish}

From analyses of these eleven cases it is clear that the applicant (plaintiff), defendant, Shalishkar/s, issue of the dispute and an expected outcome are the main elements of a Shalish. These elements constitute its structure. A Shalish is constituted based on a request for settlement of a dispute between two disputing parties in case of civil matter. It has no fixed dimension and its size and structure depend on the nature and gravity of the problem at hand (Golub, 2003: 5). Normally a Shalish is constituted with a chairman and some Shalishkars selected from the elders and leaders of the local areas. The disputants are also given the options to choose some Shalishkars for the Shalish. The Shalishkars themselves select a chairperson for the Shalish. The structure of Shalish is very simple and flexible. The main elements of the structure of a Shalish are as follows: 


\subsubsection{Disputants}

Disputants are parties involved in a dispute. The one who takes the dispute to the neutral third party (Shalishkars) for resolution is called applicant. In traditional Shalish, the statement of the applicant is called Arzi (Application). On the other hand, the accused in a dispute is called defendant and his statement is Jobab meaning reply. The applicant is called Badi (complainant/litigant) and the defendant is Bibadi (the defendant). The main objective of Shalish is to restore the relationship and social harmony.

\subsubsection{The Shalishkars (Arbitrators)}

The word Shalish is actually a neutral third party in between two disputing parties who try to settle the dispute amicably. Normally the disputants choose a Shalishkar or the Shalishkars. They are some adjudicators, mediators, arbitrators or conciliators for resolution of a dispute between the disputants. The people who are members of Shalish committee to conduct a Shalish proceeding are called Shalish (adjudicators). They are also called matbors, dana, bichari, dewani, dorbari etc. They are local notable elites who have several roles such as, according to Karim (1991), "religious and ritual activities, politico-jural functions, and economic and subsistence activities in the society" (Alim, 2004; Karim, 1991). They are generally village elders and respected personalities (Siddiki, 2003: 10). Shalish committee members usually don't have a professional knowledge of legal matters, nevertheless they know their own community and its social equilibrium better than the court and this adds significant quality to their decisions (Braun, 2010: 19). Shalishkars are generally selected on the basis of their seniority, experience, wisdom, or economic, religious, and political status (Ministry of Local Government, 2010: 28).

\subsubsection{Issue of the dispute}

A dispute may be defined as "a fact which is alleged by one party and denied by the other; and by both with some show of reason". In another word"Dispute is a problem to be solved together, rather than a combat to be won" (Akhtaruzzaman, 2013: 27). A dispute necessarily demands two opposite parties, and based on the subject matter, a dispute may be a commercial, financial, industrial, matrimonial or interpersonal dispute and so on. A dispute needs a solution.

\subsubsection{The Sulh (agreement/settlement/outcome)}

The sulh or settlement is the objective of the whole process in a Shalish. An access to justice is meaningful only when a justice seeker can exit with a justice. When Shalishkars reach a decision to avert a dispute and a written or 
an oral agreement is done, it is called sulh namah. Before the Shalishkars declare a decision, they make the disputants mentally close to each other. In this connection, a Shalishkars said:

"Before we declare the final award, we ask from the parties to do hand shake and embrace one another. It means relationship is above everything. Then we declare the award ensuring justice" (Interview 31_15032019).

Regarding the imposition of punishment in a Shalish, Shalishkars are very sincere about state law. In this regard, one of the Shalishkars said:

"It happened previously that Shalish sometimes imposed punishment in criminal matters. Nowadays Shalishkars are sincere about such an imposition, for state law does not allow them to do it" (Interview 05_30012019).

\subsection{Types of cases handled by Shalishkars/categorizing the cases}

Based on the nature of disputes, the Shalishkars identify the cases as criminal or civil cases following the categorization of cases by the formal courts in the country. It seems that traditional Shalishkears count petty criminal cases as civil cases to convince the parties easily. They try to give a message to the society that it is a fault not a crime and they should together make it correct. They deal with all the disputes occurring in a society. In our question of what type of cases the Shalishkars deal, the answer was same from all.

"We handle all types of disputes happening in our society. Even murder related dispute, which court may release the murderer for the victim party failed to prove it definitely; we handle it and settle it peacefully. We interfere all the disputes occurring in the society relying on Allah the Almighty for the wellbeing of the people" (Interview 8_31012019).

Another Shalishkear said:

"We do Shalish relating to all issues like family issues, neighbouring issues, land property, quarreling, struggling and so on. It has no fixed type. We deal murder case and settle it. We deal all that happen in our society through Shalish. The most important thing in Shalish is that if the parties accept Shalish positively, none can raise any question about it" (Interview 31_15032019).

To deal a serious criminal issue Shalishkars maintain a balance between their initiation and the legal expectation. In this connection, a Shalishkear said: 
"However, there are some cases which a court can never accept for shalish to deal like a murder case. For law does not allow a court to let a murder case be settled through an informal dispute resolution system like Shalish. In that case, we prepare both the victim and accused parties to convince their witnesses to present their statement in a way that the case tactfully may come out from the formal court to Shalish forum. Then we settle it peacefully" (Interview 32_15032019).

From the above discussion, it is clear that a Shalish deals with all types of civil or criminal, family or social disputes. Shalishkars consider all cases of disputes in the society as social problems and try to settle them socially. Disputants are always sufferer and looser by court case. So finally, they are also ready to accept Shalish mediation.

\subsection{Operational mechanism}

Regarding operational mechanism, it has been found from observation that Shalishkars are used to dividing the cases into civil and criminal. It may be that they had this idea from the formal civil and criminal court of the country. To operate a case they follow a mechanism based on their inherited knowledge. The Shalishkars hear from both applicant and defendant equally. Then they examine and cross-examine the statements and reach a decision, or go ahead for further query if needed. They collect the proper documents from both disputants for and against the claim respectively. They form a board to solve the dispute consulting with all. To reach an outcome they try their best to do it collectively and declare the decision in the voice of the chairperson. As the main objective of the Shalish is to uphold the social order and restore the relationship, Shalishkars make the contending parties come closer and embrace or shake one another's hand with a pleasant mode. Finally, they declare the decision. Operation of a Shalish may be discussed under following points:

\subsubsection{Pre-operational activities}

To operate a Shalish systematically Shalishkears have to get some preliminary tasks done. These are as follows:

1) The case must be brought to them by any of the disputing parties or by an interim neutral third party.

2) They must have the consent from both disputing parties.

3) They may have to take security money from the parties assuring that none of the parties will avoid the Shalish in its mid-way or have to mitigate some emergency cost from this deposited money and

4) the disputants must agree to comply with the decision. 


\subsubsection{Case filing in Shalish}

Normally a Shalish hearing takes place near the place where the dispute takes place. If the matter is about family dispute like conjugal maladjustment or elopement etc. where the prestige of the family/kin is related-the settlement process must take place initially within the close relatives of the disputing families. Rural people do not prefer their family matters reaching out of their hamlets or villages (Barkat et al., 2012). It starts from closely related clan initiatives. If the effort fails, village panchayat may be involved. At the failure of the village panchayat Shalish, it enters into the next circle of union parishad or Thana level. A Shalishkar of a wide circle is called porgonar bichari, or Birashir Bichari which means a Shalishkar of a greater circle. The matter is almost same both for civil or petty criminal disputes. But for severe violation of law through fighting or clash, Shalishkars have to convince the parties for a Shalish to maintain a social harmony and order. For these reasons, sometimes Shalishkars have to control everything i.e. choosing Shalishkars, time and place of Shalish, representatives of the parties and their numbers and so on. One Shalishkar reports that-

"In some cases, we forbid the parties to invite others as Shalishkars, but we take the initiative to select the Shalishkars. This is to ensure that no undesirable person enters as Shalishkar.” (Interview 10_01022019).

\subsubsection{Consent and authorization from the disputants for doing Shalish}

Consent and authorization for a Shalish from the parties involved in a dispute is very important. Shalishkars are not appointed to do it from any authority. They do it being appointed socially and morally. It may be said that whenever a case comes to them by the disputants, that is also consent from the disputants and an authorization to do Shalish. However, it is found that if the dispute is a criminal in nature, and may turn into a big fight between two disputing parties, any individual or a group of Shalishkars go to them and request them not to be engaged in fight, which may cause serious loss for both parties. Instead, they along with the prominent local Shalishkars may see it and try to settle the dispute peacefully. They convince the parties, fix a date and time and a place for doing Shalish. They try to make the parties understand that it may cause a serious consequence if the Shalish fails.

"When we see two persons or two groups are quarreling which may take shape of a bigger fight, we stop them requesting not to fight. We assure them to handle their matter taking help from other local notables. We sit for settling the dispute in time and try to settle it amicably (Interview 13_11022019). 
"If it happens that two parties are about to fight against one another, we go there and try our best to make them understand that if they fight or go to the court they will be sufferer. Then we bring them under written bondage. We write the heading of Shalish only on a plain paper and take the signature of both parties and then we proceed. It happens when we see a fighting has happened and another greater fighting may happen again (Interview 31_15032019).

Only after taking the consent and authorization the Shalishkars are prepared to do a Shalish. They just write the title of the Shalish and then take the signature of the parties. They do it in white paper or in cartage paper of 13 inches or in 300 taka stamps. They never use any blank sheet. It must bear at least the title of the Shalish, its place and date. It sometimes happens that one party without informing shalishkars goes to the court, which ultimately harasses the other party and underestimates the society as well. To prevent this cleverly act the Shalishkars take consent of the parties in written text with authorization to do Shalish. This is in relation to the traditional Shalish. Document of commitments taken by a Shalish is very simple in nature. Most often, when the Shalishkars settle a matter peacefully, they tear the document in front of gathering. When they really feel to preserve a document, they draft it as clear as needed, and keep a copy to the chairperson of the Shalish and the parties are also given their copies (Interview 31_15032019).

\subsubsection{Security money}

Security money varies from Shalish to Shalish. It may be from taka five to ten thousand, one lac to five lacs or even ten lacs. Generally, there is no misuse of security fund. In most cases, the security fund is preserved and returned back exactly. The Shalishkars maintain all kinds of transparency about security money. The chairperson has the duty to bring the security money and show it to all in every session of the Shalish meeting. Therefore, there is least chance of misuse of that fund. Even though the misuse of security fund is rare, there are some evidences of attempts by some unscrupulous Shalishkars and chairmen who misuse this fund, moor particularly when the disputants are socially and economically weak.

\subsubsection{Main operational activities}

\subsubsection{Hearings (from both applicant and defendant)}

Hearing from both applicant and defendant is the first step of a Shalish procedure. In fact, it is the first step for all judicial procedure. Shalishkear has to listen to both applicant and defendant carefully. Listening may sometimes 
be enough to conclude a Shalish if it has no relation with any property right, and both disputants are fair enough in their statements.

\subsubsection{Argumentation (Cross-examinations)}

After hearing from both applicant and defendant, Shalishkars may need some clarification. It may happen that one of the disputants or both are hiding some facts. In that case, Shalishkars ask some questions to any one or both of the disputing parties and extract some fact for all. In this stage, if they feel that the real fact has been found they try to reach a solution without wasting time. One educated Shalishkar praising local illiterate Shalishkar so highly commented that-

"Despite no academic education rural Shalishkars are so talented that you cannot imagine it. Their ability of understanding a problem, its internal fact and how should it be resolved are praiseworthy. It seems that their knowledge is God gifted" (Interview 16_02052018).

A Shalish may end in this stage also without going in details. Of course, it needs mental fairness from both disputing parties and Shalishkars as well.

\subsubsection{Evidence and documents checking}

When a dispute arises with claiming any property and the disputants are serious about their rights and none of them is to compromise, such a dispute needs evidence. The Shalishkars check it clearly and hire expert from outside or surveyor to measure if it is a land dispute. The Shalishkars in this kind of dispute has to adjudicate following the law and assure the rights of everyone.

\subsubsection{Formation of Jury Board/Shalish Board}

After the common operational activities are finished, the chairperson of the Shalish requests the audience to form a jury/Shalish board to assess the statements and arguments. Sometimes the disputing parties are given chance to choose some members from their own and some members are added from the Shalishkars. If it seems that party selection may create another problem, then they give no chance to the parties to choose board members. The Shalishkars who were from the very beginning of the problem and contributed to form the Shalish are included in the jury board. The jury board after threadbare discussion comes to a decision to settle the matter either through compromise of action or through imposition of a decision, which one fits best to settle the matter amicably.

\subsubsection{Somojuta (Compromise)/Bichar (Adjudication)}

As the Shalishkars know the causes and factors of a dispute more or less, they 
try to settle the matter through either somojuta (compromise) or bichar (arbitration). Thus Shalish involves voluntary submission to arbitration (bichar which, in this context, involves the parties agreeing to submit to the judgment of the Shalish panel), mediation (somojuta in which the panel helps the disputants to try to devise a settlement themselves) or a blend of the two. Somojuta is more informal than bichar. To settle a dispute through bichar the Shalishkars take evidences, ask the witnesses much and argue the matter. Even they get involved in debate each other. Finally, they reach a decision based on majority or unanimously. In some cases they have to form jury board for this purpose.

The chairperson of the Shalish has jurisdiction to select the members of the jury board. Sometimes the audience may choose them consulting with the chairperson. The chair of the Shalish by default is a member of the jury board also. It may happen that the jury board reaches to a unanimous decision. Sometimes they may differ but the decision is taken on majority's opinions. The jury board disclose their suggestions to the audience or to the chairperson and the chairperson formally declares the punishment or a formula to compromise the matter and to settle it peacefully.

\subsubsection{Process of decision-making}

In every stage mentioned above a dispute may come to an end. Before the decision is declared, the chairperson consults for extracting opinion of the Shalishkars or Shalish board and finally declares the decision. Every problem seems new to the Shalishkars and they have no written solution for it. Therefore, they find the solution after threadbare discussion. It may be termed as consultation to collect and process opinion of others in a raised problem. These hearing, augmenting, evidence taking and decision-making happen as parts of the total process.

\subsubsection{Implementation of decision}

In Bangladesh, traditional Shalish agreements are enforced through village peer pressure. To follow up a Shalish decision is also a very important part of a Shalish to get a fruitful end. Agreements are publicly proclaimed. Families would lose face if they do not comply with agreements. The village Shalish system relies on this traditional compliance mechanism and succeeds despite the lack of formal court enforcement. Where necessary the Shalish assigns some Shalishkars to follow up and oversee the implementation of the decision.

Implementations of Shalish decisions are not serious problem in rural areas. Because when village elders mediate and the settlement is agreed by the 
disputing parties, it is considered dishonorable for the family that fails to comply with the agreement. If one party does not comply with the agreement, the honor of the entire family is discredited (Halim, 2015). In reply to a question about the implementation of the Shalish decision, a Shalishkar stated that the Shalish committee uses necessary strategies for implementation of the decision in a dignified way. He said:

"Suppose for a criminal offence a man has to seek forgiveness from a woman. In this case, we request any local murobbi (elderly person) to be with the man when he meets the woman for asking forgiveness. He is to report back accordingly to the Shalish committee. If the case is about a land dispute, we make someone responsible to supervise it and help us giving report about its implementation" (Interview 32_15032019).

\section{Limitations of Shalish}

Every system has some limitations. Shalish as a system is not out of this truth. Some researchers detected some limitations in the traditional Shalish operations in Bangladesh. These limitations are mostly about the level of academic quality of the Shalish. As villagers are not literate in large number, most Shalishkears similarly are not found literate. However, these Shalishkears are found quite intelligent and experienced. Their experiences made them skillful in dispute resolution. In that sense, this kind of limitation is not a serious factor. Moreover, it is alleged that the traditional Shalish system is dominated by the male Shalishkars. As a result, there is an element of male biasness in its operation system. But it is true that most of the disputes are concerning male member of the society. As a result, for dispute resolution the Shalish committee having all the Shalishkears as male members may not have any bias elements in decision making. On the other hand, female members of rural community are not interested to come forward to serve as Shalishkars in the Shalish committee. Such kind of activities by the female members is not traditionally appreciated also in the society. Therefore, this allegation of gender biasness is not quite tenable. Nonetheless, now a days the government of Bangladesh and the society are encouraging the female members to serve as Shalish members in rural areas. There are also some efforts by various government agencies and NGOs to train and make them literate to the best possible level. Under these circumstances, it can be hoped that limitations of this nature in traditional Shalish operations will not exist in near future. 


\section{Conclusion and recommendations}

Shalish is a community-based dispute resolving informal institution prevailing in Indo-Bangladesh sub-continent. Panchayat was known as administrative rural unit burdened with some judicial responsibilities. With the advent of Muslim period in India Hindus feel uncomfortable to go with their disputes to formal courts, which were being administered under Islamic legal system. Therefore, panchayat acted as an alternative way of dispute resolution throughout the Muslim period in India specially for Hindus. It is not clear in which period the judicial duties of panchayat started to be known as Shalish. As the origin of the word is Arabic, it may be assumed that Islam may have any way an influence to distinguish the institution as Shalish albeit under panchayat or village community administration. Some scholars state that "Shalish is used to exercise judicial and administrative functions in the rural areas of Sri Lanka since 500 BC". Similarly, Shalish is also an age-old practice in Bangladesh (Alim \& Rafi, 2003: 5). Pre-Mughal in origin, the Shalish is the indigenous form of arbitration in rural Bengal (Samity, 2003). As long as the word "Shalish" is of Arabic origin, so it can never be used anywhere before Christian era. Using both mediation and arbitration, this village court takes place not in the formal court, but rather in the household (Ahmed, 2013). Village court is backed by local government lower unit union parishad whereas NGO-Shalish is backed up by NGOs policy. Likewise, traditional Shalish is backed by panchayat / somaj (community).

Shalish has no fixed form but its formation is an instant initiation to meet some instant needs. The underlying spirit of Shalish is to find a suitable solution for a rural dispute collectively. In finding out the solution for a problem it collects the opinions of others trough a consultative (shuratic) way. Though it has no written law to regulate, it follows a system based on tradition recorded in the memory of the people from generation after generation. In pre-British era, fatwa was a formal institution to guide formal judiciary, when Muslims were ruling India and Islam was dominant both in individual and collective life in society. It became an informal institution to guide individual and collective life through updating the day-to-day knowledge about any problem according to the holy Qur'an and the tradition of the prophet and his community. In doing so Mufti used to use the heritage of figh (Islamic Jurisprudence) supporting his fahm (understanding) and tried his best to give a proper solution for contemporary problem. After eradication of institution of fatwa from formal judiciary by British colonial rule, it remains as an informal institution for Muslim individuals. For lack of any governmental support, the institution of fatwa became weaker day by day. 
Madaripur Legal Aid Association has set an example to develop an independent modal named MMM (Madaripur Model of Mediation) for traditional Shalish. It got a general acceptance in the area where it functions its activities.

Village court may function as a model for traditional Shalish to push it ahead. In fine, legal and moral education through juma sermon in every Jame-Masjid, insertion Shalish in formal education system proportionately in National Curriculum Text Books, combined workshops program through joint initiative of NGOs and local organizations may help Shalish to improve. Non-Government Organizations (NGOs) have come forward to refashion the traditional Shalish system. They are conscious of the prime need to ensure neutrality, non-imposition and attaining a 'win-win situation' in their mediation process. As part of a priority measure, training for the Shalishkars (mostly volunteers) on the legal issues and mediation processes has been introduced by NGOs with a view to overcoming the limitations of the traditional Shalish.

\section{References}

Ahmed, F. E. (2013). The compassionate courtroom: feminist governance, discourse, and Islam in a Bangladeshi Shalish. Feminist Formations, 25(1), 157-183.

Akhtaruzzaman, M. (2013). Concept and laws on alternative dispute resolution and legal aid (5th ed.). Dhaka: Advocate Razia Khatun.

Alim, M. A. (2004). Shalish and the role of BRAC's federation: Improving the poor's access to justice. Unpublished MA thesis: Graduate School of Development Studies, The Hague.

Alim, M. A., \& Rafi, M. (2003). Shalish and the role of BRAC federation. Dhaka: BRAC Research and Evaluation Division.

Barkat, A., Paddar, A., Khan, S., \& Ullah, R. (2012). Review of social barriers and limitations of village courts. In A. A. M. S. Khan (Ed.), Activating village courts in Bangladesh project (pp. 131). Dhaka: Local Government Division.

Barman, D. C. (1988). Emerging leadership patterns in rural Bangladesh: A study. Dhaka: Centre for Social Studies.

Braun, J. P. (2010). Study on conflict in Adivasi villages (pp.41). Bangladesh: NETZ Study (Partnership for Development and Justice).

Census, B. P. H. (2011). Population and housing census 2011. Dhaka: Statistics and Informatics Division, Ministry of Planning.

Delwar, J. (2005). Shalish-mediation in Rural Bangladesh. E-journal Samaj Kantha: Voice for the Society, 58. 
Golub, S. (2003). Non-state justice systems in Bangladesh and the Philippines. United Kingdom: Department for International Development.

Halim, M. A. (2015). ADR in Bangladesh: Issues and challenges (6th ed.). Dhaka: CCB Foundation.

Hoque, M. A. (Ed.) (2018) Byaboharik Bangla Abbidhan (18th ed., Vol. 1). Dhaka: Bangla Academy.

Islam, F. (2000). Towards a brief history of alternative dispute resolution in rural Bangladesh. Bangladesh Journal of Law, 4(1\& 2).

Islam, M. (2012). Institutionalization of grassroots level alternative dispute resolution (ADR): Challenges and prospects. Unpublished MA thesis: North South University, Bangladesh.

Islam, S. (2003). Banglapedia: National encyclopedia of Bangladesh. In S. Islam \& S. Miah (Ed.), Banglapedia. Dhaka: Asiatic Society of Bangladesh.

Islam, Z. (2009). Strengthening state-led rural justice in Bangladesh: Views from the bottom. Dhaka: CCB Foundation.

Islam, Z. (2015). Strengthening state-led rural justice in Bangladesh: Views from the bottom (2nd ed.). Dhaka: CCB Foundation

Karim, A. Z. (1991). The samaj activities and leadership role in rural Bangladesh. South Asian Anthropologist, 12, 1-10.

Lewis, D., \& Hossain, A. (2005). Understanding the local power structure in rural Bangladesh. Dhaka: Report for SIDA,

Muhammad, S. (Ed.) (2000) Bangladesher Ancholik Bhashar Obhidhan (4th ed.). Dhaka: Bangla Academy.

Munni, M. M. (1996). Informal systems and village courts: Poor people's preference. In Human Security in Bangladesh - In Search of Justice and Dignity.

Ministry of Local Government.(2010). Baseline survey report on village courts in Bangladesh. Dhaka: Activating Village Courts in Bangladesh Project. Retrieved from https://www.undp.org/content/dam/bangladesh/docs/Projects/Villa ge $\% 20$ Court/2016/Baseline\%20Survey\%20Report.pdf

n.a. (n.d). Organisation of Judicial System in India: Pre-Constitutional Era Organisation of Judicial System in India (pp. 64). n. pl: n. pb.

Samity, S. M. (2003). Shalishi in West Bengal a community-based response to domestic violence. Economic and Political Weekly, 1665-1673.

Sarker, M. N. I. (2013). An evaluation of village court: A study on selected village courts Bangladesh. Unpublished MA thesis: Governance and development, BRAC University, Bangladesh. 
Shahidullah, M. (Ed.). (2009). Bangladesher Anchalik Bhashar Abhidhan (3rd ed.). Dhaka: Bangla Academy.

Siddiki, D. M. (2003). Paving the way to justice: The experience of nagorik uddyog. One World Action, 1-28.

\section{Corresponding author}

Muhammad Rafiqul Hoque can be contacted at: rafique20012000@yahoo.com 